Chirurgia (2021) 116: 7-15

No. 1, January - February

Copyright@ Celsius

\title{
Robotic Revisional Experience. Single Centre Prospective Cohort Study and Review of the Literature
}

\author{
Ramon Vilallonga ${ }^{1,2^{*}}$, Arturo Cirera de Tudela ${ }^{3}$, Elsa García Möller ${ }^{3}$, Laura Vidal Piñeiro ${ }^{3}$, Marta Barros Segura ${ }^{3}$, \\ Meritxell Pera Ferreruela ${ }^{3}$, Rodrigo Mata Mata ${ }^{3}$, Enric Caubet', Oscar Gonzalez', Amador Garcia Ruiz de Gordejuela', \\ Andrea Ciudin ${ }^{4,5,6}$, José Manuel Fort', Manuel Armengol Carrasco ${ }^{3}$
}

\author{
'Endocrine, Metabolic and Bariatric Unit, Department of General and Digestive Surgery, Vall d'Hebron University Hospital, \\ Universitat Autònoma de Barcelona. Center of Excellence for the EAC-BC, Barcelona, Spain \\ ELSAN, Clinique Saint Michel, Centre Chirurgical de I'Obésité, Toulon, France \\ ${ }^{3}$ Department of General and Digestive Surgery, Vall d'Hebron University Hospital, Universitat Autònoma de Barcelona, Spain \\ ${ }^{4}$ Institut de Recerca Vall d'Hebron, Universitat Autònoma de Barcelona (VHIR-UAB), Barcelona, Spain \\ ${ }^{5}$ CIBER de Diabetes y Enfermedades Metabólicas Asociadas. Instituto de Salud Carlos III, Spain \\ ${ }^{6}$ Endocrinology and Nutrition Department, Hospital Universitari Vall Hebron, Barcelona, Spain
}

${ }^{*}$ Corresponding author:

Ramon Vilallonga, MD, PhD

Endocrine, Metabolic and Bariatric

Unit, Vall d'Hebron University

Hospital, Universitat Autònoma de

Barcelona

Center of Excellence for the EAC-BC

Passeig de la Vall d'Hebron 119-129

08035 Barcelona, Spain

E-mail: vilallongapuy@gmail.com

\section{Rezumat}

Experiență în procedurile revizionale robotice. Studiu prospectiv de cohortă efectuat într-un centru unic și sinteza literaturii de specialiatate

Introducere: Chirurgia bariatrică robotică (CBS) a crescut semnificativ în ultimii ani. În orice caz, CBS reprezintă o provocare tehnică comparativ cu chirurgia bariatrică primară sau „clasică”. In prezent există multe incertitudini legate de complicațiile postoperatorii, costurile şi aspectele tehnice ale acesteia. Prezentăm în acest articol experiența centrului nostru cu privire la utilitatea CBS în chirurgia revizională.

Metode: A fost efectuată o revizuire retrospectivă a experienței noastre, precum şi o revizuire a literaturii pentru a evalua impactul CBS în domeniul chirurgiei revizionale.

Rezultate: Un total de 17 pacienți (5 femei şi 12 bărbați) au fost operați. Cea mai frecventă intervenție chirurgicală a fost SADI-S secvențial (a doua etapă) $(n=6)$ şi conversia gastrectomiei verticale la bypass gastric $(\mathrm{n}=9)$ RE-DO bypass gastric (2). Nu s-au înregistrat complicații severe. Din revizuirea sistematică a literaturii am obținut rezultate similare, inclusiv un număr scăzut de complicații atunci când se efectuează o intervenție chirurgicală robotică revizională.

Concluzii: Chirurgia robotică revizională prezintă rezultate mai bune comparativ cu chirurgia bariatrică „clasică” laparoscopică 
standard, în ceea ce priveşte eficacitatea, siguranța şi durata internării. Nu s-au observat diferențe în ratele de mortalitate, morbiditate şi reintervenție între ambele abordări. Încurajăm chirurgii să învețe să efectueze tehnica robotică ca parte a procesului de democratizare şi standardizare a chirurgiei bariatrice.

Cuvinte cheie: chirurgia robotică, Da Vinci, chirurgiei bariatrice, revizională, SADI-S, conversia

\begin{abstract}
Background: Robotic bariatric surgery (RBS) has increased in recent years. Many doubts continue to exist regarding its utility in terms of postoperative complications, costs and technical aspects. RBS has increased its number and shows a more technical challenge associated with more post-operative complications compared to primary bariatric surgery. We herein present a single institution experience and review to describe its utility in revisional surgery.

Methods: A retrospective review of our experience and a review of the literature has been conducted to evaluate the impact of robotic revisional surgery in the bariatric field.

Results: A total of 17 patients (5 female and 12 male) were operated on. Most frequent surgery was conversion of sleeve gastrectomy to gastric bypass $(n=9)$. No leaks were found nor severe complications. A systematic review showed similar results including a decreased number for complications when performing robotic revisional surgery.

Conclusions: Revisional robotic surgery shows better results compared to standard laparoscopic revisional bariatric surgery in terms of efficacy, safety and hospital stay. No differences were seen in rates of mortality, morbidity and reintervention between both approaches. We encourage surgeons to learn to perform the robotic technique as part of the process of democratization and standardization of bariatric surgery.
\end{abstract}

Key words: robotic surgery, Da Vinci, bariatric surgery, revisional, SADI-S, conversion

\section{Introduction}

Bariatric surgery has been proved to reduce the risk for the development of medical complications such as diabetes mellitus, cardiovascular diseases or even cancer (1-2). Furthermore, Morbid Obese (MO) patients associate a myriad of metabolic derangements, such as type 2 diabetes mellitus (T2DM), which could also justify some of the postoperative complications seen in this kind of patients, including the gastrointestinal leak (3). Bariatric robotic surgery has evolved a lot since 1998 when Himpens et al. published the first case of bariatric robotic procedure (4). Revisional bariatric surgery is required in 10 to $56 \%$ of cases (5). It is, in fact, the fastest growing category of bariatric procedures, having grown from $6 \%$ in 2013 to $15.4 \%$ in 2018 (6). Main causes are inadequate weight loss, weight regain, or complications related to the primary procedure. The increased number of bariatric procedures worldwide and the number of reoperative procedures will most likely continue to increase in the coming years. Revisional bariatric surgery (RBS) is challenging and technically more demanding, requiring a specific approach (5-8). Thus, postoperative complications, such as anastomotic Leak (AL) and bleeding have been shown to be higher in laparoscopic surgery compared to robotic surgery (RobS) (9-12). Reoperative bariatric surgery includes 3 types of procedures such as revisions, corrections where the anatomy of the initial procedure is preserved. These procedures are often performed to 
manage complications of an effective procedure, such as redo of a gastrojejunal anastomosis because of intractable marginal ulcer or stricture. Corrections can include adhesiolisis, correcting abnormalities on the anastomosis, closing possible gastro-gastric pouch fistulas or anything that could be the cause of weight regain. Also, adding restriction by reducing a large pouch or a large stoma or increasing malabsorption by adding a longer Roux or biliopancreatic limb should be considered corrective procedures. Second, conversions which are defined when a primary bariatric procedure is converted to a different bariatric procedure. Insufficient weight loss, weight regain, or recurrence of obesity-related comorbidities are the most frequent reasons leading to this type of revisions. (eg, conversion from a AGB or vertical banded gastroplasty to an gastric bypass (GBP) or sleeve gastrectomy). Third, reversals that include the return to a normal anatomy from the primary bariatric procedure, where the original anatomy is restored. In this article, we aim to review the impact of robotic revisional surgery in terms of postoperative complications in our literature and review the literature related to RBS and RobS.

\section{Materials and Methods}

A retrospective review of the cases who underwent robotic revisional bariatric surgery at our center (Vall d'Hebron University Hospital) was carried out, in which epidemiological data such as age, sex, and previous obesity-related pathologies were analyzed. Clinical data was collected after 30 days of the date of the intervention in each patient, including type of surgery performed, total operative time, overall morbidity, hospital stay and 30-days post-operative complications.

In addition to this, a literature review was conducted to evaluate the evidence supporting the different treatment approaches for robotassisted bariatric surgery and a comparison between this technique with the laparoscopic approach in terms of weight loss results and complications. We carried out (AC, EGM and
RV) a systematic research of the following metasearch engines including the period from the platform inception through December 2020: PubMed, Embase, MEDLINE, Cochrane Central Register of Controlled Trials, and the main clinical trial databases (the International Clinical Trials Registry Platform Search Portal and ClinicalTrials.gov) for on-going studies. The search strategy included keywords such as "robotic-assisted bariatric surgery", "robotics AND bariatric surgery", "robotic revisional bariatric surgery", "robotic Roux-en-Y gastric bypass", "robotic sleeve gastrectomy" and "laparoscopic bariatric surgery". Gray literature, as well as references named in the published studies, were also analysed to ensure not missing relevant articles.

There was no discrimination by language. Finally, the following data was deduced from the included articles: study main features (author, journal, year of publication and type of study), demographic characteristics (number of patients included, age, gender, baseline BMI), type of procedure, number and types of complications, follow-up and weight loss results.

\section{Results}

The results of the review of cases operated on in our center are shown in Table 1. In total, 17 patients underwent robotic revisional bariatric surgery, 5 of whom were women, and the rest were men. The mean age was 33 years and mean operative time vas 180 minutes. Previous comorbidities included T2DM, hypertension, dyslipidemia, and obstructive sleep apnea syndrome. Most frequent surgery was conversion of sleeve gastrectomy to gastric bypass (GBP) $(n=9)$. Two (2) patients underwent a re-do surgery from GBP (Fig. 1). In the end, the postoperative complication rate was $5.88 \%$ of the total, specifically, one case of reoperation in the first days after surgery in a second stage SADI-S. Mean length of hospital stay was 2.4 days. In the end, no major intraoperative nor post-operative complications such as gastro-intestinal bleeding, anastomot- 


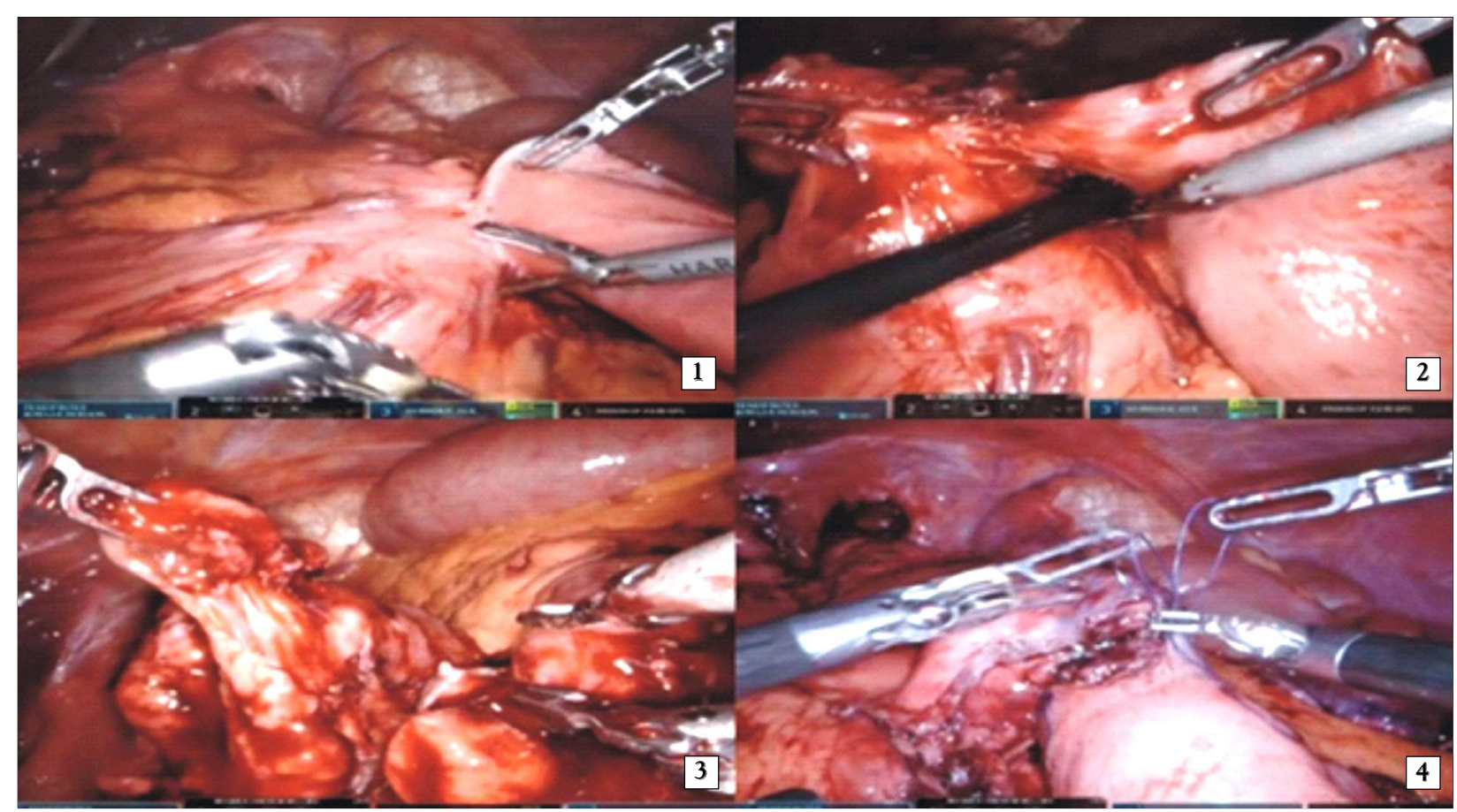

Figure 1. Image showing: 1) Marginal ulcer of the anastomosis highly adhered to the anterior wall of the antrum (gastro-gastric fistula); 2) Massive adhesiolysis and opening of the fistula of the gastro-entero anastomosis on the remnant stomach; 3) Complete bypass dissection with closure of the remnant fistula; resection of the anastomosis and alimentary limb; 4) Reconstruction of the gastric bypass with a hand sewed anastomosis.

ic and/or gastric pouch leak, deep vein thrombosis/pulmonary embolism, or surgical site infection were found.

On the other hand, 257 papers were screened for review by three authors (AC, EGM and RV). After applying our inclusion and exclusion criteria, 5 of them were finally analysed to obtain information about robotic bariatric revisional surgery (Table 2). Having a total number of 2,443 patients, the overall complication rate ranges between $0-8.8 \%$, being the most common one the anastomotic leak in conversions from adjustable gastric band (AGB), revisional GBP and SADI-S and postoperative bleeding in the staple line in sleeve gastrectomy. Other complications that must be considered are marginal ulcer, ventral hernia, pulmonary embolism, gastrojejunal anastomosis stricture, wound infection, pneumonia and urinary tract infection. No differences were found in morbidity, mortality and reintervention rates when comparing revisional robot assisted GBP and the laparos- copic approach. In addition, RRBS is associated with a shorter length of stay than LRBS in complex procedures and has at least an equivalent safety profile. There were no clear data on costs and most papers focus on the feasibility of the technique with the use of robotic platforms.

\section{Discussion}

Bariatric robotic surgery has evolved a lot since 1998 when Himpens et al. published the first case of bariatric robotic procedure (4). As it is described in EAES consensus statement on the use of robotics in general surgery (1314), robotic surgery provides 6 degrees of freedom of movement, greater precision, 3D vision and comfort for the operator, all of them are characteristics that should facilitate surgery in an obese patient, who characteristically has thin walls, fatty liver, and large dimensions (15). All these features could be helpful for the execution of complex bariatric 
Table 1. Demographic data, outcomes and 30 days complications of patient with revisional robotic surgery in our Institution

\begin{tabular}{lc}
\hline & $\begin{array}{c}\text { Revisional robotic bariatric } \\
\text { surgery (n=17) }\end{array}$ \\
\hline AGE (years) & 54 \\
Median & $32-65$ \\
Range & 5 out of $17(29.41 \%)$ \\
GENDER & 12 out of $17(70.59 \%)$ \\
Female & \\
Male & 33 \\
\hline PREOPERATIVE BMI (Kg/M²) & $24-56$ \\
Median & $29.4 \%$ \\
Range & $47.0 \%$ \\
PREVIOUS CO-MORBIDITES (\%) & $47.0 \%$ \\
Diabetes Mellitus & $47.1 \%$ \\
Hypertension & \\
Dyslipidemia & 6 \\
OSAS/CPAP & 9 \\
TYPES OF SURGERIES PERFORMED (n) & 2 \\
SG to SADI-S & 180 minutes \\
Conversion from SG to GBP & $(150-240$ minutes) \\
Re-Do GBP (gastro-gastric fistula) to GBP & $1(5.88 \%)$ \\
\hline OUTCOMES & \\
Total operative time (minutes, range) & $0(0.0 \%)$ \\
Overall Morbidity. (n, \%) & $0(0.0 \%)$ \\
\hline Intraoperative complications. (n, \%) & $0(0.0 \%)$ \\
Blue test leak & $0(0.0 \%)$ \\
Bleeding & 2.4 days \\
Perforation & $0(0.0 \%)$ \\
Leak & $0(0.0 \%)$ \\
\hline Length of hospital stay (days) & $0(0.0 \%)$ \\
\hline 30 DAYS COMPLICATIONS. (n, \%)) & $0(0.0 \%)$ \\
Deep vein thrombosis & $0(0.0 \%)$ \\
Pulmonary embolism & $0(0.0 \%)$ \\
Pneumonia & $1(5.88 \%)$ \\
Wound infection/seroma & $0(0.0 \%)$ \\
Urinary tract infection & $0(0.0 \%)$ \\
Gastrointestinal bleeding & $0(0.0 \%)$ \\
Re-operations 30 days & $0(0.0 \%)$ \\
Pouch or G-J anastomotic leak & \\
J-J anastomotic leak/intestinal lesions & \\
Intra-abdominal bleeding & \\
Other reasons & \\
\hline Abbreviations: BMI body mass index, OSAS/CPAP obstructive sleep apnea \\
syndrome and continuous positive airway pressure; SG: Sleeve gastrectomy; \\
GBP (Roux en Y Gastric Bypass) & \\
\hline
\end{tabular}

surgery techniques that may need include handsewn anastomosis, manipulation of different abdominal quadrants, such as the GBP, duodenal switch, SADI-S or redo bariatric surgery. Most studies carried out to date, have shown a similar complication rate as conventional laparoscopic surgery. No differences were found in the incidence of reoperations, bleeding, leakage, or stenosis compared to laparoscopic surgery $(14,15)$. Due to the lack of number of cases, we did not perform a comparative study of laparoscopic revisional surgery and robotic revisional surgery. However, data shown in Table 1, and according to our review, are like those published by other authors. Also, robotic bariatric surgery has been proved to be less cost effective, longer operating times and higher costs, compared to laparoscopic bariatric surgery (16). It has been described that in complicated revisional bariatric surgery a robotic approach may confer a shorter hospital stay (17). In our data, hospital stay remains very low (2-3 days), being according to our standard of care. On the other hand, the learning curve in robotic surgery is shorter than in laparoscopy. More studies need to be done to determine the role of robotic bariatric surgery.

This surgery is technically challenging, due to adhesions and altered anatomy caused by the first one (7). Because of this, operative time is also longer (8). The type of revisional procedure and the number of prior foregut or bariatric operations determine perioperative morbidity, and it depends on the original technique and the indications for revision (9). It is important to establish if the cause of failure is anatomic or behavioural (10). Once decided a surgical revision is necessary, the next step is to choose the needed technique. Reoperative bariatric surgery includes 3 types of procedures as defined previously: 1) revisions, corrections 2) conversions such as sleeve gastrectomy to SADI-S as a second stage as in our experience with the revisional procedures described in table $1 ; 3$ ) reversals that although we have recently published the review of a fist cohort of patients, we do not have experience yet in robotic reversal. Current literature shows an increased morbidity in revisional bariatric surgery compared to primary procedures (10-12). However, this morbidity can be acceptable in experienced hands (10). As in our short experience, data suggest that major complications should at least be less than $2 \%$ of the cases. It is also as effective as primary surgery in achieving a maintained weight loss (11). Furthermore, general 


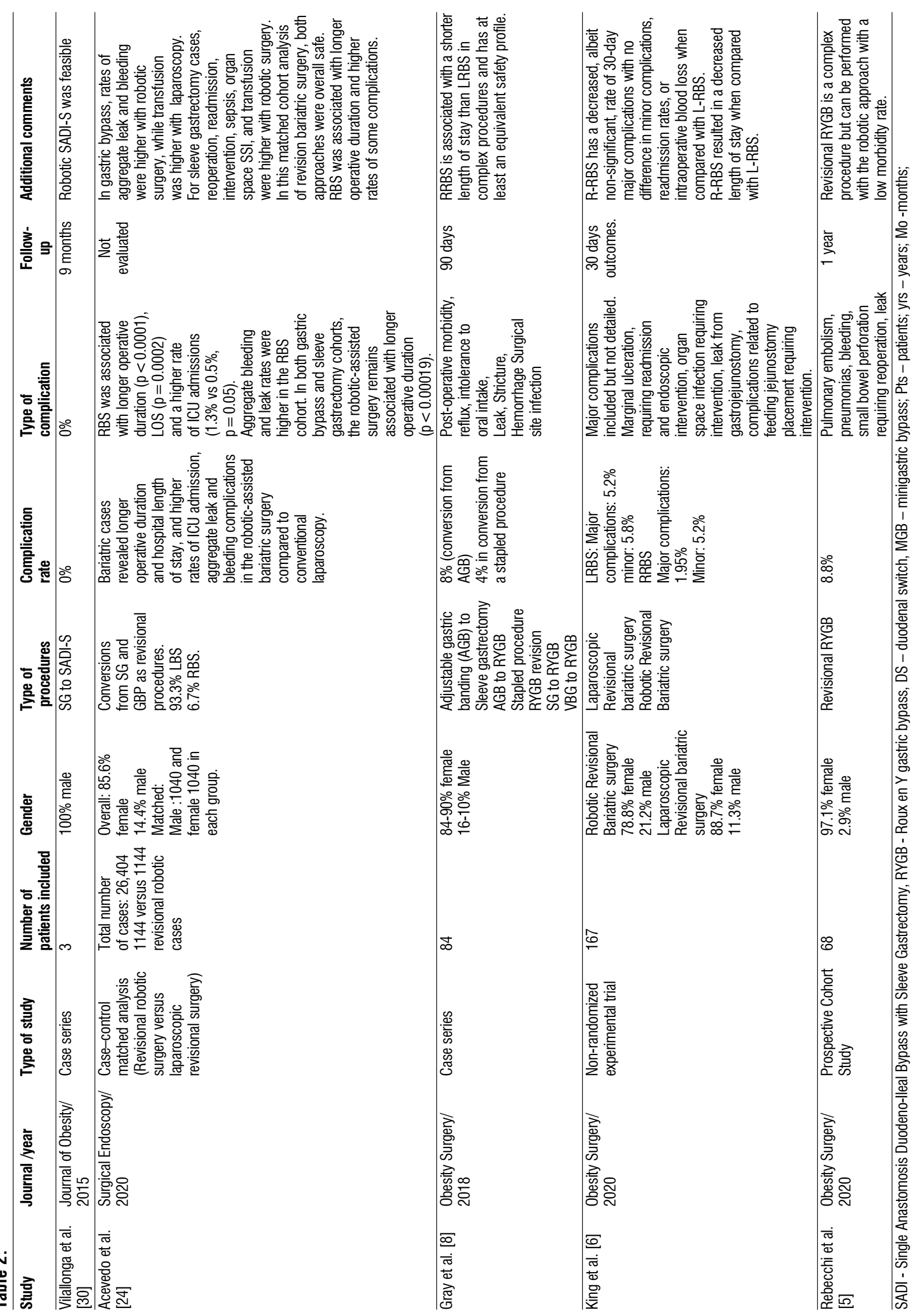


advantages of robotic surgical systems over traditional laparoscopy include threedimensional high-definition visualization, tremor filtration, and direct camera control by the surgeon and wristed instruments, which make relatively complex laparoscopic tasks such as suturing easier (18-19). In the field of bariatric surgery, these advantages should be translated into a decreased number of leaks or even anastomotic stenosis, due to the ability to perform fully handsewn anastomosis versus the more commonly performed stapled anastomoses with the laparoscopic approach (20).

Revisional bariatric surgery includes the usual difficulties of surgery in patients with obesity, such as visceral fat, hepatomegaly and abdominal wall thickness. Furthermore, reoperative surgery adds the challenge of working in a more complex abdomen with a certain degree of adhesions, modified tissue planes or novel complications (marginal ulcer, gastro-gastric fistula). In our experience, we had two cases of marginal ulcer complicated with gastro-gastric fistula. These differences with primary procedures explain the higher complications rates (in leaks and bleeding) seen after laparoscopic reoperative bariatric surgery, with leak rates ranging from $6 \%$ to $22 \%$ (21-23). Robotic surgery can offer a higher facility to perform handsewn anastomosis, articulated instruments and 3-dimensional high-definition visualization could potentially result in a more precise dissection and better handling of tissues, which might result in better postoperative outcomes.

From our data extraction, some studies such as the analysis of the MBSAQIP database shows that revisional robotic bariatric surgery might have some issues to be solved. The case-matched study from Acevedo demonstrated longer operative time, increased hospital length of stay, and increased rate of unplanned intensive care unit admissions with robotic revisional bariatric surgery (23). Our mean operative time was 180 minutes and ranged from 150 to 240 minutes. This time is longer compared to our laparoscopic revisional surgery. Further studies should be done to understand the reason of this increased time. The MBSAQIP database has been evaluated specifically comparing laparoscopic versus robotic revisional bariatric surgery and showed an increased operative time and length of stay for robotic-assisted revisional surgery (24). We need however to mention that there is a difficulty in analysing the data as all cases are mixed and it is difficult to comment on the effects of patient selection (24-25).

Several studies have suggested potential advantages of the robotic approach, with lower laparotomy conversion rates, lower leak rates, and shorter lengths of hospital stay compared with laparoscopic surgery (26-28). There is a lack of large, randomized studies such as our short experience review, but data suggest that robotic surgery may provide the highest benefit for reoperative bariatric surgery.

This review has some limitations. It has not specifically compared the impact of robotic versus laparoscopic surgery and has not focused on costs related to the systems and on the overall process. However, costs related to the robotic systems include initial purchase, maintenance, and disposable parts. The advent of new robotic platforms in the market and others that will come soon, currently being developed by several companies across the world, will stimulate market competition and decrease overall costs. Surgeon experience and the learning curve will play a critical role as well because shorter operating times decrease overall costs and will result in higher income by allowing more revisional surgeries to be performed.

\section{Conclusions}

Even though robotic surgery offers potential technological advantages, its widespread adoption has been limited by high costs, a difficult adoption and longer operative times compared with traditional laparoscopy in the bariatric field. The increased number of primary bariatric procedures and its need to revisional procedure which implied a higher complication rates have led to the robotic approach is associated with often conflicting 
data. Primary outcomes such as anastomotic stricture and leak rates have been analysed with a non-uniform result. Novel changes in robotic platforms and technology will complicate even more the robotic results and impact in the study analyses. Our results suggest that once a learning-curve is established, revisional bariatric surgery can be attempted with robotic approach. We encourage surgeons to learn to perform the robotic technique as part of the process of democratization and standardization of bariatric surgery. Larger multicentre experiences and analysis of data are needed to help clarify the role of robotics in primary and revisional bariatric surgery.

\section{Acknowledgments}

The authors want to acknowledge the Vall Hebron Campus hospital for its trust in robotic surgery program.

\section{Conflicts of Interest and Source of Funding}

The authors have no conflict of interest and the article has received no source of funding.

\section{References}

1. Sjöström L, Peltonen $M$, Jacobson $P$, Sjöström $C D$, Karason $K$ Wedel $\mathrm{H}$, et al. Bariatric surgery and long-term cardiovascular events. JAMA. $2012 ; 307(1): 56-65$.

2. Sundbom M, Hedberg J, Marsk R, Boman L, Bylund A, Hedenbro J, et al. Scandinavian Obesity Surgery Registry Study Group. Substantial Decrease in Comorbidity 5 Years After Gastric Bypass: A Population-based Study From the Scandinavian Obesity Surgery Registry. Ann Surg. 2017;265(6):1166-1171.

3. Mandviwala T, Khalid U, Deswal A. Obesity and Cardiovascular Disease: a Risk Factor or a Risk Marker? Curr Atheroscler Rep. 2016;18(5):21.

4. Cadiere GB, Himpens J, Vertruyen M, Favretti F. The world's first obesity surgery performed by a surgeon at a distance. Obes Surg. 1999:9(2):206-9.

5. Rebecchi F, Ugliono E, Allaix ME, Toppino M, Borello A, Morino M Robotic Roux-en-Y Gastric Bypass as a Revisional Bariatric Procedure: a Single-Center Prospective Cohort Study. Obes Surg. 1 de enero de 2020;30(1):11-7.

6. King K, Galvez A, Stoltzfus J, Claros L, El Chaar M. RoboticAssisted Surgery Results in a Shorter Hospital Stay Following Revisional Bariatric Surgery. Obes Surg (Internet). 19 de octubre de 2020 (citado 13 de diciembre de 2020); Disponible en: https://doi.org/10.1007/s11695-020-05022-0

7. Nasser H, Munie S, Kindel TL, Gould JC, Higgins RM. Comparative analysis of robotic versus laparoscopic revisional bariatric surgery: perioperative outcomes from the MBSAQIP database. Surg Obes Relat Dis. 1 de marzo de 2020;16(3):397-405.
8. Gray KD, Moore MD, Elmously A, Bellorin 0, Zarnegar R, Dakin G, et al. Perioperative Outcomes of Laparoscopic and Robotic Revisional Bariatric Surgery in a Complex Patient Population. Obes Surg. 1 de julio de 2018;28(7):1852-9.

9. Shimizu H, Annaberdyev S, Motamarry I, Kroh M, Schauer PR, Brethauer SA. Revisional Bariatric Surgery for Unsuccessful Weight Loss and Complications. Obes Surg. 1 de noviembre de 2013;23(11):1766-73.

10. Lo Menzo ES, Szomstein S, Rosenthal RJ. Reoperative bariatric surgery. In: Nguyen NT, BRP, Morton JM, et al, editors. The ASMBS textbook of bariatric sur gery, vol. 1. New York: Springer; 2015. p. 269-82.

11. Stefanidis D, Malireddy K, Kuwada T, Phillips R, Zoog E, Gersin KS. Revisional bariatric surgery: perioperative morbidity is determined by type of procedure. Surg Endosc. diciembre de 2013;27(12): 4504-10.

12. Jones KB. Revisional bariatric surgery-potentially safe and effective. Surg Obes Relat Dis. 1 de noviembre de 2005;1(6):599-603.

13. Szold A, Bergamaschi R, Broeders I, Dankelman J, Forgione A, Langø T, et al. European Association of Endoscopic Surgeons. European Association of Endoscopic Surgeons (EAES) consensus statement on the use of robotics in general surgery. Surg Endosc. 2015;29(2):253-88. Epub 2014 Nov 8.

14. Fourman MM, Saber AA. Robotic bariatric surgery: a systematic review. Surg Obes Relat Dis. 2012;8(4):483-8.

15. Wilson EB, Sudan R. The evolution of robotic bariatric surgery. World J Surg. 2013;37(12):2756-60.

16. Gill RS, Al-Adra DP, Birch D, Hudson M, Shi X, Sharma AM, Karmali S. Robotic-assisted bariatric surgery: a systematic review. Int J Med Robot. 2011 Sep;7(3):249-55.

17. Scozzari G, Rebecchi F, Millo P, Rocchietto S, Allieta R, Morino M. Robot-assisted gastrojejunal anastomosis does not improve the results of the laparoscopic Roux-en-Y gastric bypass. Surg Endosc. 2011;25(2):597-603. Epub 2010 Jul 13.

18. Corcione F, Esposito C, Cuccurullo D, Settembre A, Miranda N, Amato $F$, et al. Advantages and limits of robot assisted laparoscopic surgery: preliminary experience. Surg Endosc. 2005;19(1):117-9. Epub 2004 Nov 18.

19. Van Koughnett JA, Jayaraman S, Eagleson R, Quan D, van Wynsberghe A, Schlachta CM. Are there advantages to roboticassisted surgery over laparoscopy from the surgeon's perspective? J Robot Surg. 2009;3(2):79-82.

20. Ho C, Tsakonas E, Tran K, Cimon K, Severn M, Mierzwinski-Urban $\mathrm{M}$, et al. Robot-assisted surgery compared with open sur gery and laparoscopic surgery. CADTH Technol Overv. 2012;2(2):e2203. Epub 2012 Jun 1.

21. Abdelgawad M, De Angelis F, lossa A, Rizzello M, Cavallaro G, Silecchia G. Management of complications and outcomes after revisional bariatric surgery: 3-year experience at a bariatric center of excellence. Obes Surg. 2016;26(9):2144-2149.

22. Shimizu H, Annaberdyev S, Motamarry I, Kroh M, Schauer PR, Brethauer SA. Revisional bariatric surgery for un successful weight Ioss and complications. Obes Surg. 2013;23(11):1766-73.

23. Brethauer SA, Kothari S, Sudan R, Williams B, English WJ, Brengman $\mathrm{M}$, et al. Systematic review on reoperative bariatric surgery: American Society for metabolic and bariatric surgery revision task force. Surg Obes Relat Dis. 2014;10(5):952-72. Epub 2014 Feb 22.

24. Acevedo E, Mazzei M, Zhao H, Lu X, Edwards MA. Outcomes in conventional laparoscopic versus robotic-assisted revisional bariatric surgery: a retrospective, case controlled study of the MBSAQIP database. Surg Endosc. 2020;34(4):1573-1584. Epub 2019 Jun 17.

25. Clapp B, Liggett E, Jones R, Lodeiro C, Dodoo C, Tyroch A. Comparison of robotic revisional weight loss surgery and laparoscopic revisional weight loss surgery using the MBSAQIP database. Surg Obes Relat Dis. 2019;15(6):909-919. 
26. Scarritt T, Hsu CH, Maegawa FB, Ayala AE, Mobily M, Ghaderi I. Trends in Utilization and Perioperative Outcomes in Roboticassisted Bariatric surgery using the MBSAQIP database: A 4-Year Analysis. Obes Surg. 2020 Nov 9. Epub ahead of print.

27. Tatarian T, Yang J, Wang J, Docimo S, Talamini M, Pryor AD, et al. Trends in the utilization and perioperative outcomes of primary robotic bariatric surgery from 2015 to 2018: a study of 46,764 patients from the MBSAQIP data registry. Surg Endosc. 2020 Jul 31. Online ahead of print.

28. Bindal V, Bhatia P, Dudeja U, Kalhan S, Khetan M, John S et al. Review of contemporary role of robotics in bariatric surgery. $J$ Minim Access Surg. 2015;11(1):16-21.

29. Dudash M, Kuhn J, Dove J, Fluck M, Horsley R, Gabrielsen J, et al. The Longitudinal Efficiency of Robotic Surgery: an MBSAQIP
Propensity Matched 4-Year Comparison of Robotic and Laparoscopic Bariatric Surgery. Obes Surg. 2020;30(10):37063713.

30. Gray KD, Moore MD, Elmously A, Bellorin 0, Zarnegar R, Dakin G, et al. Perioperative outcomes of laparoscopic and robotic revisional bariatric surgery in a complex patient population. Obes Surg. 2018; 28(7):1852-1859.

31. Snyder B, Wilson T, Woodruff V, Wilson E. Robotically assisted revision of bariatric sur geries is safe and effective to achieve further weight loss. World J Surg. 2013;37(11):2569-73.

32. Buchs NC, Pugin F, Azagury DE, Huber O, Chassot G, Morel P. Robotic revisional bariatric surgery: a comparative study with laparoscopic and open surgery. Int J Med Robot. 2014;10(2):2137. Epub 2013 Oct 24. 